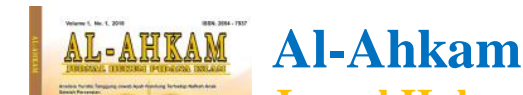

Jurnal Hukum Pidana Islam

Volume 1, No. 1, 2018

ISSN (print) : 2654-7937

ISSN (online) : xxxx-xxxx

Homepage :http://journal.al-ahkam.iaims.ac.id

\title{
TINDAK PIDANA YANG DILAKUKAN PARA REMAJA DI KABUPATEN BONE (ANALISIS YURIDIS DAN KRIMINOLOGIS)
}

\author{
ST. Hadijah Wahid
}

\begin{abstract}
Abstrak
Dalam penulisan ini membahas masalah Tindak Pidana yang Dilakukan Para Remaja di Kabupaten Bone (Analisis Yuridis dan Kriminologis)Hal ini dilatarbelakangi oleh banyaknya tindak pidana yang dilakukan oleh remaja dan kurang adanya penegakan hukum yang tegas dalam menangani kasus tersebut. Sehingga perlu diketahui tindak pidana yang dilakukan para remaja di Kabupaten Bone, Faktor apa saja yang dapat menyebabkan terjadinya tindak pidana yang ditimbulkan oleh para remaja, bagaimanakah tinjauan yuridis dan kriminologis dari tindak pidana yang dilakukan para remaja, serta upaya-upaya apa saja yang dilakukan oleh penegak hukum untuk mengatasinya.Metode yang dipakai adalah yuridis empiris, meninjau masalah yang diteliti dari segi ilmu hukum serta melihat dan mengaitkan dengan kenyataan yang ada. Berdasarkan hasil penelitian, penulis memperoleh jawaban atas permasalahan yang ada, bahwa keadaan tindak pidana yang dilakukan oleh para remaja di Kabupaten Bone sekarang ini sering terjadi perkelahian antara grup remaja baik dalam lingkup sekolah maupun lingkungan masyarakat umum. Faktor yang menjadi penyebab timbulnya tindak pidana di kalangan anak atau remaja, adalah sebagai berikut: Faktor Lingkungan, Faktor Ekonomi, Faktor Keluarga. Tinjauan yuridis dan kriminologis dari tindak pidana yang dilakukan para remaja yaitu menurut KUHP, UU tentang peradilan anak, UU tentang perlindungan anak. Upayaupaya yang dilakukan polisi dalam mengatasi masalah tersebut adalah: [1] Penanggulangan Preventif: upaya pencegahan untuk terjadinya suatu tindak pidana (contoh: mengadakan penyuluhan ke sekolah-sekolah, pendekatan terhadap orang tua, pendekatan terhadap pemuka masyarakat). [2] Penangulangan Represif: penanggulangan yang dilakukan setelah terjadinya tindak pidana, yang berupa tindakan-tindakan untuk memberantas tindak pidana dengan menggunakan upaya hukum untuk melakukan penangkapan, menyita barang bukti, melakukan penyidikan sampai ke pengadilan.
\end{abstract}

Kata Kunci: Tindak Pidana, Remaja, Analisis Yuridis, Kriminologis.

\section{Pendahuluan}

\section{a. Latar Belakang Masalah}

Sebagaimana kita ketahui bahwa pada akhir-akhir ini tindak pidana yang dilakukan oleh remaja semakin meningkat, meresahkan masyarakat dan 


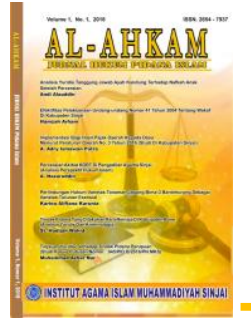

menyebabkan terjadinya kejahatan-kejahatan yang dilakukan oleh anak atau remaja. Hal ini dapat kita ketahui melalui berbagai massa media yang antara lain : radio, surat kabar, televisi, majalah, serta media cetak lainnya dan bahkan dari internet yang memberi kita informasi mengenai masalah kejahatan yang dilakukan oleh remaja tersebut.

Tindak pidana yang dilakukan para remaja sudah menjadi masalah di semua negara.Setiap tahun tingkat kenakalan para remaja ini menunjukan peningkatan, sehingga mengakibatkan terjadinya problema sosial.Lingkungan sangat berpengaruh besar dalam pembentukan jiwa remaja.Bagi remaja yang ternyata salah memilih tempat atau kawan dalam bergaulnya. Maka yang akan terjadi kemudian adalah berdampak negatif terhadap perkembangan pribadinya. Tetapi, bila dia memasuki lingkungan pergaulan yang sehat, seperti memasuki organisasi pemuda yang resmi diakui oleh pemerintah, sudah tentu berdampak positif bagi perkembangan kepribadiannya.

Tindak pidana para remaja akhir-akhir ini yang sangat mengkhawatirkan adalah akibat pengaruh dari lingkungan sosial. Gejala-gejala kejahatan yang muncul merupakan akibat dari proses perkembangan pribadi remaja yang sedang berupaya mencari identitas diri. Masa remaja merupakan masa-masa yang penuh dengan gejolak.Masa remaja juga rentan dengan berbagai permasalahan yang cukup kompleks dan pelik.Karena di masa inilah seseorang bertumbuh dan menjalani saat mencari jati diri untuk membentuk karakter kepribadian.

Wilayah Kabupaten Bone yang merupakan salah satu bagian dari daerah di Sulawesi Selatan mengalami perkembangan yang pesat di segala bidang pembangunan. Di lain sisi, gemerlap kehidupan kota Bone yang lain menggambarkan kemajuan ekonomi tersirat dari berbagai atribut kemakmuran. Di daerah Bone sekarang ini di kalangan anak sekolah maupun yang tidak sekolah atau tidak berpendidikan sudah marak adanya kenakalan remaja, dimana terdapat anak yang merokok, perkelahian, sikap-sikap brutal lainnya.

Mengenai kenakalan remaja kita tidak dapat menyalahkan mutlak sepenuhnya, bahwa remajalah yang bersalah.Karena remaja sebelum menginjak 


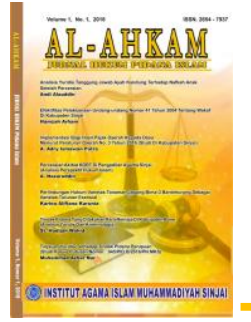

masa remajanya, tentu melewati masa anak- anak yang tidak terlepas dari bimbingan orang tua dan juga keberadaan lingkungan tempat tinggalnya. Dalam hal ini penulis analisa bahwa masa anak- anak adalah cikal bakal yang akan membentuk kepribadian menjadi remaja yang dewasa dan berbudi luhur bila pada masa anak-anak mereka dididik dengan baik, teratur, diberi kasih sayang dan perhatian yang cukup.

Dampak dari perubahan sosial yang pesat ini dapat di lihat pada sikap dan perilaku masyarakatnya.Meningkatnya penyimpangan perilaku sosial merupakan salah satu akibat yang harus diterima oleh masyarakat yang sedang membangun, masyarakat yang sedang mengalami perubahan kearah masyarakat modern.Penyimpangan-penyimpangan yang dilakukan oleh remaja, sehingga berbuah timbulnya suatu kejahatan dewasa ini menjadi suatu permasalahan yang serius dan mengkhawatirkan serta harus segera ditanggulangi. Berdasarkan hal tersebut diatas, maka penulis tertarik meneliti tentang "Tindak Pidana yang Dilakukan Para Remaja di Kabupaten Bone (Analisis Yuridis dan Kriminologis)”

\section{b. Hasil Penelitian}

Untuk melengkapi penulisan yang dilakukan ini, maka dalam bab ini penulis menyajikan data yang diperoleh selama masa penelitian berhubungan dengan tindak pidana kenakalan remaja dalam timbulnya kejahatan di kota Bone. Data yang disajikan diperoleh dengan membahas permasalahan dan melalui analisa kasus yang terjadi serta penyajian dari hasil metode kuesioner di lapangan.Dan kemudian dianalisa, dengan maksud untuk menemukan kebenaran sesuai dengan hukum yang berlaku.

\section{Tindak Pidana Yang Dilakukan Oleh Para Remaja Di Kota Bone}

Berdasarkan hasil penelitian yang dilakukan di Kota Bone yang bersumber pada wawancara dan data Kepolisian Polres kota Bone, keadaan tindak pidana yang dilakukan oleh para remaja di Kabupaten Bone sekarang ini sering terjadi perkelahian antara grup remaja baik dalam lingkup sekolah maupun lingkungan masyarakat umum, dan sudah sangat meresahkan masyarakat. Tindak pidana kenakalan remaja 


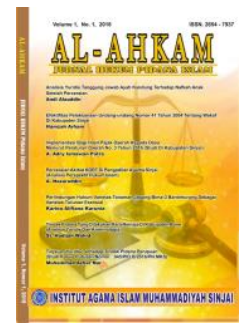

Al-Ahkam

Jurnall Hulkum Pidana Islam

Volume 1, No. 1, 2018

ISSN (print) : 2654-7937

ISSN (online) : xxxx-xxxx

Homepage :http://journal.al-ahkam.iaims.ac.id

perlu perhatian khusus dari pihak yang berwenang dalam hal ini pemerintah dan pihak Kepolisian.

\section{Faktor-Faktor Yang Menyebabkan Terjadinya Tindak Pidana}

Dari hasil wawancara yang telah dilakukan pada Kanit Ppa Polres Bone diperoleh data bahwa yang menyebabkan tindak pidana yang dilakukan para remaja yaitu faktor yang paling banyak yaitu dari faktor lingkungan, karena lingkunganlah yang sangat berpengaruh pesat pada kejahatan yang dilakukan anak-anak maupun para remaja, dan adapun penjabaran tentang faktor - faktor yang menyebabkan tindak pidana tersebut yaitu :

\section{1) Faktor Lingkungan}

Faktor lingkungan tempat dimana para pelaku tinggal. Hal ini dapat dibuktikan dari data yang diperoleh, bahwa pelaku tindak pidana yang melakukan perbuatan melawan hukum karena terpengaruh oleh lingkungan tempat tinggalnya. Keadaan lingkungan yang kumuh, miskin dan terbelakang menyebabkan pelaku terbawa pada perilaku yang menyimpang.Remaja banyak belajar dari lingkungan sekitarnya, sebagai lingkungan bermain remaja cepat beradaptasi dan belajar dari orang-orang sekitarnya.Sehingga lingkungan yang tidak baik dapat mempengaruhi tingkah laku anak remaja.

\section{2) Faktor Ekonomi}

Keadaan ekonomi yang berada dibawah standar kelayakan.Faktor ini menjadi penyebab utama mengapa pelaku melakukan perbuatan melawan hukum. Keadaan ekonomi yang buruk menjadikan mereka berbuat kebablasan hanya untuk mengejar uang atau impian yang tidak bisa dicapai, sehingga pelaku memiliki kecenderungan untuk menghalalkan segala cara meskipun perbuatan yang dilakukannya melawan hukum.

\section{3) Faktor Keluarga}

Keluarga yang kurang memperhatikan. Faktor ini menjadi asal mula dari timbulnya kenakalan anak atau remaja tersebut, keluarga yang tidak mengerti kebutuhan anaknya menyebabkan pelaku bertindak menyimpang. Para pelaku 


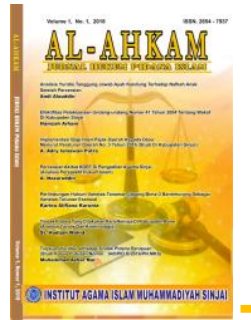

Al-Ahkam

Jurnall Hulkum Pidana Islam

Volume 1, No. 1, 2018

ISSN (print) : 2654-7937

ISSN (online) : xxxx-xxxx

Homepage :http://journal.al-ahkam.iaims.ac.id

tindak pidana ini melakukan perbuatan melawan hukum sebagai akibat dari kurangnya keluarga mereka memperhatikan keinginan sang anak.

Akhlak anak dibentuk bermula di rumah.Anak sejak kecil dan sebagian besar waktunya dihabiskan dalam lingkungan keluarga.Anak belajar dari sikapdan perilaku kedua orangtuanya.Sebagian besar kenakalan remaja ini dipengaruhi oleh pendidikan di rumah. Beberapa hal dalam rumahtangga yang berpengaruh;

1. Rendahnya pendidikan agama dalam rumahtangga, fungsi kedua orangtua gagal dalam menunjukkan tabiat dan akhlak yang sesuai dengan nilai agama. Misalnya saja; anak diharuskan shalat oleh orangtua akan tetapi sang anak tidak pernah melihat kedua orangtuanya shalat

2. Status ekonomi yang rendah mengakibatkan kedua orangtuanya mesti bekerja keras sehingga anaknya tidak mendapatkan kebutuhan kasih-sayang yang cukup

3. Perilaku kedua orangtua sendiri yang tidak bermoral

4. Kedua orangtuanya lebih mementingkan kerja atau pekerjaan dibandingkan mengontrol dan mengawasi anak-anaknya

5. Keluarga broken home.

\section{Tinjauan Yuridis tentang Tindak Pidana Kenakalan Remaja}

\section{a. Tinjauan KUHP}

Secara yuridis formal, masalah pertanggung jawaban mengenai kenakalan anak atau remaja yang dapat menimbulkan kejahatan ini telah memperoleh pedoman yang baku dalam hukum. Pertama-tama adalah hukum pidana yang pengaturannya tersebar dalam beberapa pasal, dan sebagian pasal yang bersifat embrional adalah Pasal 45, 46 dan 47 KUHP. Di samping itu KUHP pun mengatur tentang kenakalan remaja terutama dalam Pasal 320 dan segala pasal yang ditunjuk serta terkait dengan masalah kenakalan remaja ini.

Berdasarkan pada Undang-Undang RI No 3 Tahun 1997 Tentang Peradilan Anak, kepada anak remaja nakal yang melakukan tindak pidana dapat pula dijatuhkan tindakan :

a. Mengembalikan kepada orang tua, wali, atau orang tua asuh; 


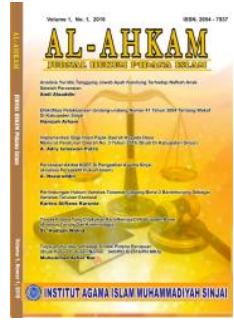

b. Menyerahkan kepada negara untuk mengikuti pendidikan, pembinaan, dan latihan kerja; atau

c. Menyerahkan kepada Departemen Sosial, atau Organisasi Sosial Kemasyarakatan yang bergerak dibidang pendidikan, pembinaan, dan latihan kerja.

Tindakan yang dijatuhkan sebagaimana putusan yang ditetapkan diatas dapat disertai pula dengan memberikan teguran dan syarat tambahan yang ditetapkan oleh hakim. Mengenai penjatuhan pidana, Undang-Undang RI Nomor 3 Tahun 1997 menetapkan bahwa penjatuhan pidana terdiri dari Pidana penjara, Pidana Kurungan, Pidana Denda, dan penjatuhan Pidana Bersyarat.

Mengenai perlindungan anak ini, sebelum Undang-Undang RI Nomor 23 Tahun 2002 diberlakukan, bangsa Indonesia menggunakan Undang-Undang RI Nomor 4 Tahun 1979 tentang Kesejahteraan Anak. Dalam Undang-Undang tersebut dijelaskan bahwa usaha-usaha mensejahterakan anak dan perlakuan yang adil terhadap anak sangat diperlukan. Sebagaimana yang dijelaskan dalam Pasal 1 butir b Undang-Undang RI Nomor 4 Tahun 1979 tentang Kesejahteraan Anak, bahwa :

"Usaha kesejahteraan anak adalah usaha kesejahteraan sosial yang ditujukan untuk menjamin terwujudnya Kesejahteraan Anak terutama terpenuhinya kebutuhan pokok anak".

Pengaturan mengenai ketentuan-ketentuan yang berhubungan dengan perlindungan anak dalam Undang-Undang RI Nomor 23 Tahun 2002 adalah :

1. Anak adalah seseorang yang belum berusia 18 (delapan belas tahun ), termasuk anak yang masih dalam kandungan.

2. Perlindungan anak adalah segala kegiatan untuk menjamin dan melindungi anak dan hak-haknya agar dapat hidup, tumbuh, berkembang, dan berpartisipasi, secara optimal sesuai dengan harkat dan martabat kemanusiaan, serta mendapat perlindungan dari kekerasan dan diskriminasi.

Tindakan ini dimaksudkan untuk mewujudkan kehidupan terbaik bagi anak remaja yang diharapkan sebagai penerus bangsa yang potensial, tangguh, 


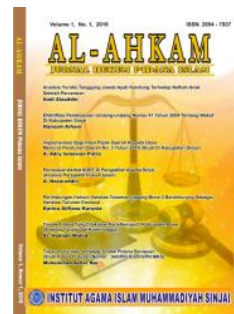

Al-Ahkam

Jurnal Hukum Pidana Islam

Volume 1, No. 1, 2018

ISSN (print) : 2654-7937

ISSN (online) : :xxxx-xxxx

Homepage :http://journal.al-ahkam.iaims.ac.id

memiliki nasionalisme yang dijiwai oleh akhlak mulia dan nilai Pancasila, serta

berkemauan keras menjaga kesatuan dan persatuan bangsa dan negara Indonesia. 


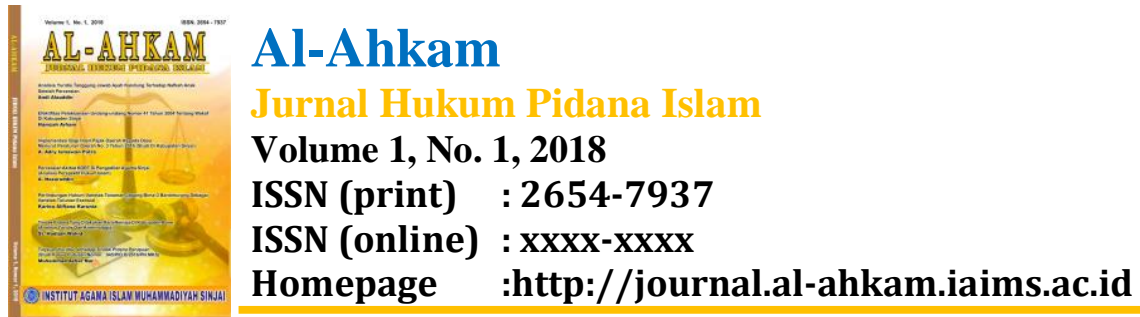

\section{Tinjauan Kriminologis Tindak Pidana Kenakalan Remaja}

Kenakalan remaja yang pada zaman yang semakin modern ini semakin mencemaskan dan menjurus pada timbulnya kejahatan, yang sangat dikhawatirkan pada masa depan bangsa dan Negara Indonesia kelak. Hal ini tentunya menjadi suatu permasalahan pokok, karena remaja merupakan buah yang akan dipetik keberadaannya demi kelangsungan kehidupan berbangsa dan bernegara dimasa depan nanti.

Kenakalan remaja yang dilakukan dapat berupa kenakalan yang berkelompok.Hal ini dapat diketahui dengan banyaknya jumlah pelaku kejahatan yang dilakukan oleh remaja yang terjadi di dalam masyarakat. Dalam perkembangan masyarakat seperti ini, pengaruh budaya di luar sistem masyarakat sangat mempengaruhi perilaku anggota masyarakat itu sendiri, terutama anakanak, lingkungan, khususnya lingkungan sosial, mempunyai peranan yang sangat besar terhadap pembentukan perilaku anak-anak, termasuk perilaku jahat yang dilakukan oleh anak-anak.

Beberapa waktu terakhir ini, banyak terjadi kejahatan atau perilaku jahat di masyarakat. Dari berbagai massa media, baik elektronik maupun cetak, kita selalu mendengar dan mengetahui adanya kejahatan atau perilaku jahat yang dilakukan oleh anggota masyarakat. Pelaku kejahatan atau pelaku perilaku jahat di masyarakat tidak hanya dilakukan oleh anggota masyarakat yang sudah dewasa, tetapi juga dilakukan oleh anggota masyarakat yang masih anak-anak atau yang biasa kita sebut sebagai kejahatan anak atau perilaku jahat anak.

Fakta menunjukkan bahwa semua tipe kejahatan anak itu semakin bertambah jumlahnya dengan semakin lajunya perkembangan industrialisasi dan urbanisasi.Kejahatan yang dilakukan oleh anak-anak pada intinya merupakan produk dari kondisi masyarakatnya dengan segala pergolakan sosial yang ada di dalamnya.Kejahatan anak ini disebut sebagai salah satu penyakit masyarakat atau penyakit sosial. Penyakit sosial atau penyakit masyarakat adalah segala bentuk tingkah laku yang di anggap tidak sesuai, melanggar norma-norma umum, adat- 


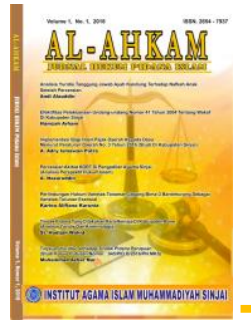

istiadat, hukum formal, atau tidak bisa diintegrasikan dalam pola tingkah laku umum.

Dalam wujudnya kenakalan remaja tersebut membawa dampak psikologis di dalam masyarakat.Sama halnya kejahatan yang dilakukan oleh orang dewasa, kejahatan yang dilakukan oleh anak remaja ini, sudah barang tentu memiliki jenis-jenis kejahatan.

Jenis-jenis kejahatan tersebut yaitu :

1. Kenakalan yang menimbulkan korban fisik pada orang lain; perkelahian, perkosaan, perampokan, pembunuhan dll.

2. Kenakalan yang menimbulkan korban materi ; perusakan, pencurian, pencopetan, pemerasan dll.

3. Kenakalan sosial yang tidak menimbulkan korban di pihak orang lain ; pelacuran, penyalahgunaan obat. Di Indonesia mungkin dapat juga dimasukan hubungan seks sebelum menikah dalam jenis ini.

Kejahatan anak dalam dasawarsa lalu, belum menjadi masalah yang terlalu serius untuk dipikirkan, baik oleh pemerintah, ahli kriminologi , penegak hukum, praktisi sosial maupun masyarakat umumnya. Ketentuan kejahatan anak atau di sebut delikuensi anak diartikan sebagai bentuk kejahatan yang dilakukan anak dalam titel-titel khusus dari bagian KUHP dan atau tata peraturan perundang-undangan.Spesifikasi delikuensi anak menjadi masalah sosial dan sekaligus hukum yang telah ada dan tumbuh bersama perkembangan dan peradaban masyarakat agama, sosial, dan hukum.Di Indonesia masalah delikuensi anak belum begitu banyak disoroti oleh sistem peradilan dan penegakan hukum pada masyarakat.

\section{Usaha Aparat Penegak Hukum Dalam Penanggulangan TerhadapKejahatan Yang Ditimbulkan Oleh Para Remaja}

Dalam upayanya untuk menjaga dan melindungi warga masyarakat kota Bone dari ancaman kejahatan yang ditimbukan oleh anak atau remaja ini, aparat penegak hukum khususnya Kepolisian Resort Bone bagian Reskrim telah mengupayakan cara penanggulangan seperti yang telah dijelaskan di atas. Baik itu 


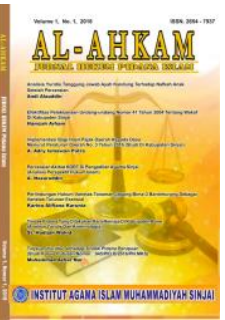

dalam tindakan preventif dan represif. Upaya-upaya yang dilakukan oleh pihak kepolisian adalah dengan cara :

a. Melaksanakan pembinaan dan penyuluhan ke sekolah-sekolah tentang :

1. Kenakalan remaja.

2. Narkoba.

\section{Pengetahuan lalu lintas}

4. Kamtibmas.

b. Melaksanakan operasi penertiban (pemeriksaan tas siswa-siswi) di sekolah.

c. Melaksanakan patroli dan sambang pada jam-jam rawan perkelahian pelajar.

d. Pembentukan PKS (Patroli Keamanan Sekolah).

Ditanamkan juga pada remaja, norma - norma sosial untuk berperilaku suka menolong sesama, yang terdiri dari dari norma timbal balik, norma tanggung jawab sosial, serta norma keseimbangan.Yang menjadi kendala di era sekarang ini adalah adanya globalisasi informasi melalui media internet. Tentunya sulit melakukan pengawasan terhadap remaja dalam mengkonsumsi media informasi global tersebut. Kemudahan remaja mengakses situs porno dan situs lainnya yang bisa mengarahkan remaja ke perilaku kenakalan remaja. Untuk itu penanaman moral dengan benar harus dilakukan maksimal guna menimbulkan " self controll " dan " self defence " pada remaja.

Kondisi fisik dan sosial lingkungan keluarga dan pergaulan remaja harus diusahakan positif dan kondusif bagi perkembangan jiwa remaja yang sedang dalam tahap labil atau peralihan dari anak - anak ke dewasa untuk menemukan jatidirinya. Dengan faktor - faktor diatas, diharapkan remaja bisa menempuh masa-masa " sulitnya" dengan positif dan berhasil guna bagi kehidupan dewasanya kelak.

Pada kategori ini berlaku bagi remaja yang telah melakukan penyimpangan atau kenakalan guna dapat kembali ke jalur yang positif serta menadakan kemungkinan untuk mengulangi kembali perilaku negatifnya. Disini penulis menganggap pemerintah memegang peranan yang sentral, sebagai amanat 


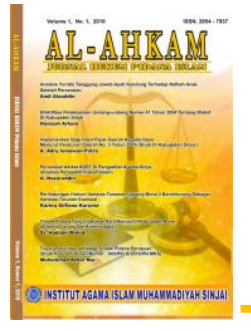

Al-Ahkam

Jurnal Hulkum Pidana Islam

Volume 1, No. 1, 2018

ISSN (print) : 2654-7937

ISSN (online) : xxxx-xxxx

Homepage :http://journal.al-ahkam.iaims.ac.id

konstitusi yaitu kewajiban negara menjamin kualitas hidup warga negaranya termasuk remaja. Yang termasuk dalam upaya ini adalah pembangunan pusat pusat rehabilitasi bagi remaja yang terjerumus ke dunia narkoba serta badan pembinaan sosial remaja yang terjerumus dalam premanisme, kejahatan pelecehan seksual, kejahatan dengan kekerasan ( seperti tawuran).

Kenyataan yang ada saat ini, usaha pemerintah khususnya Departemen Sosial belum maksimal dalam mengatasi permasalahan remaja ini. Minimnya jumlah pusat rehabilitasi dan kurang berfungsi dan profesionalnya Departemen Sosial apalagi yang ada di daerah - daerah, mencerminkan bahwa penanganan kenakalan remaja masih memprihatinkan. Permasalahan kenakalan remaja atau tindak pidana yang dilakukan oleh anak juga mendapat perhatian serius dari pemerintah Indonesia. Dimana hak-hak anak dan aturan tentang penanganan anak nakal telah diundangkan ke dalam bentuk aturan hukum formal. Perlindungan terhadap hak-hak anak diatur dalam Undang-undang RI No. 23 Tahun 2002 tentang perlindungan anak. Perlindungan anak yang dimaksudkan di sini adalah kegiatan yang dilakukan untuk menjamin dan melindungi anak dan hak-haknya agar dapat hidup, tumbuh, berkembang, dan berpartisipasi secara optimal sesuai dengan harkat dan martabat kemanusiaan, serta mendapat perlindungan dari kekerasan dan diskriminasi (Pasal 1 UU RI No.1 23 Th 2002). Di dalam undangundang ini juga diatur bagaimana negara, pemerintah, masyarakat, keluarga, dan orang tua berkewajiban dan bertanggung jawab terhadap penyelenggaraan perlindungan anak.

Dengan demikian, proses peradilan anak nakal dari sejak ditangkap, ditahan, diadili, dan pembinaan selanjutnya, wajib dilakukan oleh pejabat khusus yang benar-benar memahami masalah anak. Oleh karena itu dalam menghadapi masalah anak nakal, orang tua dan masyarakat sekelilingnya seharusnya lebih bertanggung jawab terhadap pembinaan, pendidikan, dan pengembangan perilaku anak tersebut.

\section{Penyajian Data Hasil Kuesioner}




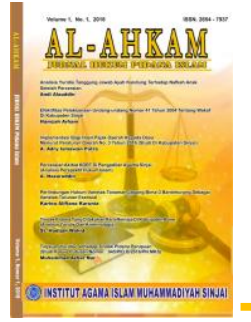

Al-Ahkam

Jurnal Hukum Pidana Islam

Volume 1, No. 1, 2018

ISSN (print) : 2654-7937

ISSN (online) : xxxx-xxxx

Homepage :http://journal.al-ahkam.iaims.ac.id

Adapun data yang penulis peroleh di lapangan dengan cara mengajukan daftar pertanyaan (kuesioner) kepada narasumber, dapat disajikan hasil penelitian tentang kenakalan remaja sebagai salah satu perbuatan yang menyimpang dan cenderung menimbulkan kejahatan dengan keberfungsian di Kota Bone. Adapun ukuran yang dipergunakan penulis untuk mengetahui kenakalan remaja seperti yang disebutkan dalam skripsi ini, yaitu : (1) Kenakalan Biasa, (2) Kenakalan yang menjurus pada tindak kriminal, dan (3) Kenakalan Khusus yang pengaturannya terdapat dalam Hukum Pidana Khusus. Responden dalam penelitian menggunakan metode kuesioner ini berjumlah 60 orang, dengan rincian responden dari anak atau remaja 20 orang, dari guru 20 orang, dan masyarakat umum 20 orang.

Dari hasil penelitian, seluruh responden pernah melakukan kenakalan, baik itu kenakalan yang tingkat rendah maupun yang tingkat tinggi, kenakalan yang di lakukan responden kebanyakan dalam lingkungan sekitarnya, meskipun ada juga di lingkungan sekolahnya.Anak remaja juga kadang terpengaruh atas ajakan temannya untuk melakukan kejahatan. Oleh karna itu anak remaja perlu lingkungan dan teman yang baik, agar tidak terpengaruh atas lingkungan dan teman yang mempengaruhinya, karna kejahatan yang dilakukan oleh teman juga kadang berdampak pada anak remaja tersebut. Oleh karena itu anak perlu lingkungan dan teman yang baik, agar tidak terpengaruh atas lingkungan dan teman yang mempengaruhinya, karna kejahatan yang dilakukan oleh teman juga kadang berdampak pada anak tersebut. Para penegak hukum belum terlalu efisien dalam menanggulani kejahatan anak tersebut karna kenakalan remaja masih meningkat, dan sangat memprihatinkan.

\section{PENUTUP}

Dari keseluruhan uraian mengenai "Tindak Pidana Yang Dilakukan Oleh Para Remaja Di Kota Bone". Adapun dari hasil penelitian dan uraian yang telah dijabarkan, maka penyusun mengambil kesimpulan sebagai berikut : 


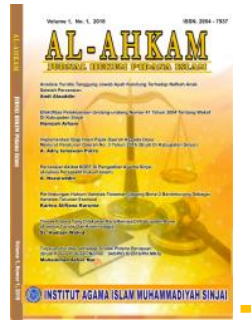

Al-Ahkam

Jurnal Hulkum Pidana Islam

Volume 1, No. 1, 2018

ISSN (print) : 2654-7937

ISSN (online) : xxxx-xxxx

Homepage :http://journal.al-ahkam.iaims.ac.id

1. Bahwa tindak pidana yang dilakukan para remaja yang terjadi di daerah Bone sudah memprihatinkan, baik itu berupa kejahatan tingkat rendah maupun kejahatan yang tingkat tinggi, kejahatan yang dilakukan para remaja semakin waktu semakin menimbulkan kecemasaan dan sudah melampaui batas-batas kewajaran.

2. Faktor -faktor yang mempengaruhi tindak pidana yang dilakukan para remaja yaitu :

a. Faktor lingkungan

b. Faktor ekonomi

c. Faktor keluarga

Dari faktor-faktor tersebut, yang dominan mempengaruhi tindak pidana yang dilakukan para remaja di daerah Bone yaitu kebanyakan dari faktor lingkungan, karna dari faktor lingkungan inilah anak remaja menjadi melakukan kejahatan dan pelanggaran.

3. Dari tinjauan yuridis, tindak pidana yang dilakukan para remaja di Kota Bone sudah menjurus pada pelanggaran KUHP pasal 351, pasal 362, dan pasal 290. Dan secara kriminologis kecendrungan kriminal sudah membudaya dan dapat menimbulkan keresahan bagi masyarakat.

4. Dari hasil penelitian, aparat penegak hukum ini belum terlalu efisien dalam menanggulangi tindak pidana yang dilakukan oleh para remaja. Meskipun aparat penegak hukum disini sudah mengupayakan dalam menanggulangi kenakalan anak remaja di wilayah Kota Bone.

\section{SARAN}

Kenakalan remaja yang dapat menimbulkan kejahatan harus segera dibenahi dan diperbaiki, terlebih jika kenakalan itu bukanlah proses mereka untuk mencapai tahap pendewasaan diri. Namun, sekalipun menjadi bagian dari proses psikologisnya, perbuatan kenakalan anak atau remaja tersebut tetap harus dibatasi agar tidak menjadi kebiasaan dan bersifat permanent dalam diri mereka. Mengabaikan keadaan anak remaja yang berlaku menyimpang ini dan membiarkannya berkembang, akan menyebabkan timbulnya akhlak yang buruk, 


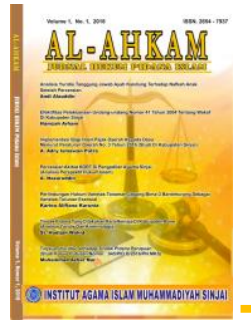

Al-Ahkam

Jurnall Hulkum Pidana Islam

Volume 1, No. 1, 2018

ISSN (print) : 2654-7937

ISSN (online) : xxxx-xxxx

Homepage :http://journal.al-ahkam.iaims.ac.id

gangguan psikologis, dan berbagai dampak negatif lainnya yang bersifat kejiwaan. Tentunya anak remaja yang rusak dalam jiwanya akan dapat merugikan bangsa dan negara Indonesia.

Anak remaja adalah sesuatu yang harus dilindungi dengan baik, keselamatan jiwa mereka teramat bergantung pada keadaan sekitarnya yang sehat dan mendukung. Agar penyelesaian permasalahan kenakalan remaja yang berpotensi menimbulkan kejahatan lebih optimal dan tercapai dalam tingkat keberhasilannya, maka penulis sekiranya dapat menyampaikan saran-saran :

1. Pengenalan terhadap hukum dan norma-norma yang berlaku secara umum dalam lingkungan keluarga, sehingga dapat mendidik anak remaja berlaku baik dan memiliki kedisiplinan khususnya pada diri anak remaja tersebut.

2. Menciptakan kondisi lingkungan tempat tinggal yang sehat, memberikan pengawasan dan bimbingan baik di bidang sosial maupun di bidang rohani.

3. Pemerintah dan aparat penegak hukum yang berwibawa, menegakkan hukum sesuai dengan peraturan yang menyangkut permasalahan mengenai anak seperti yang diatur dalam KUHP Pasal 45, 46 dan 47. UndangUndang RI Nomor 3 Tahun 1997 tentang Peradilan Anak dan UndangUndang RI Nomor 23 Tahun 2002 tentang Perlindungan Anak.

4. Bagi bangsa dan negara Indonesia diharapkan menyelesaikan permasalahan kenakalan remaja dengan bijaksana, karena anak Indonesia adalah aset berharga yang nilainya pun tidak dapat disamai dengan seribu gunung emas.

\section{DAFTAR PUSTAKA.}

Kartono, Kartini. 1979.Pathologi social Kenakalan Remaja.Jakarta: Rajawali Pers.

Lamintang. 1997.Dasar-Dasar untuk mempelajari Hukum Pidana yang Berlaku di Indonesia.Bandung: PT Citra Aditya Bakti.

Moeljatno.2011.Kitab Undang-Undang Hukum Pidana. Jakarta: Bumi Aksara.

Mulyono, Bambang. 1990. Pendekatan Analisis Kenakalan Remaja dan Penanggulangannya.Bandung: Armico. 


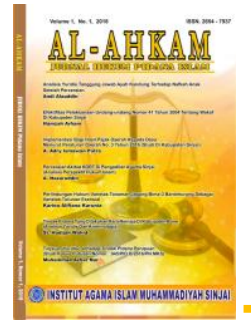

\author{
Al-Ahkam \\ Jurnal Hukum Pidana Islam \\ Volume 1, No. 1, 2018 \\ ISSN (print) : 2654-7937 \\ ISSN (online) : xxxx-xxxx \\ Homepage :http://journal.al-ahkam.iaims.ac.id
}

Republik Indonesia. 2002. Perundangan tentang anak. Yogyakarta: Pustaka Yustisia.

Republik Indonesia. 2005. "Undang-Undang Nomor 23 Tahun 2002 tentang" Perlindungan Anak. Bandung: Citra Umbara.

Republik Indonesia. 1999. "Undang-Undang Nomor 3 Tahun 1997 tentang" Peradilan Anak

Republik Indonesia. 1985. "Undang-Undang Nomor 4 Tahun 1979. tentang” Kesejahteraan Anak. Jakarta: Sekretariat Negara Republik Indonesia.

Sudarsono. 2008. Kenakalan Remaja.Jakarta: Rineke Cipta.

Sudarto. 1990.Hukum Pidana 1.Semarang: Yayasan Sudarto Fakultas Hukum Universites Diponegoro.

Susilo, Dr. dan Drs. Pramudji R. 2007.Kitab Undang-Undang Hukum Perdata. Jakarta: Wacana Intelektual.

Sutedjo, Wagiati. 2010.Hukum pidana anak.Cet. III; Bandung: Refika Adit 


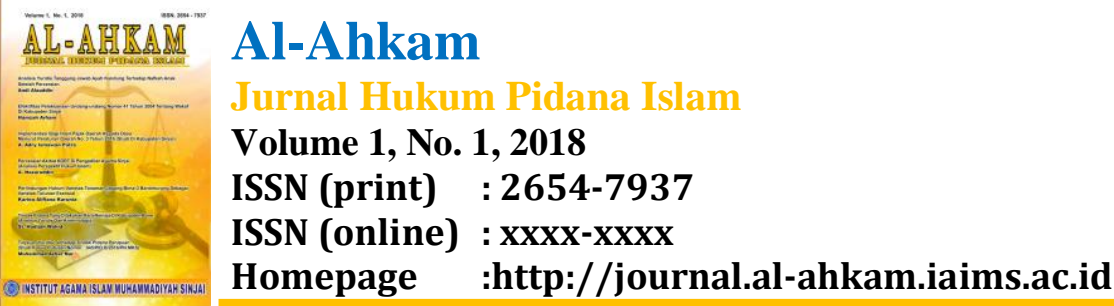

